\title{
The Influence of Islamic Brand Personality towards Bank Muamalat Surabaya Brand Loyalty
}

\section{Achsania Hendratmi ${ }^{1}$ and Bayu Laksana ${ }^{2}$}

${ }^{1}$ Department of Shariah Economics - Faculty of Economics and Business - Universitas Airlangga

${ }^{2}$ Undergraduate Student of Islamic Economics - Faculty of Economics and Business, Universitas Airlangga

\section{Abstract}

This study aimed to discern the influence of brand personalities which are Siddiq (Honest), Amanah (Trustworthy), Fatanah (Professional), and Tabligh (Communicative) - derived from Islamic Prophet Muhammad personality - towards brand loyalty of the customers of Bank Muamalat Surabaya. The primary data in this study was collected by questionnaire with 111 customers as the sampling. The researcher used quantitative method and multiple linear regression analysis. The exogenous variable in this study

Corresponding Author: Achsania Hendratmi achsania.hendratmi@feb .unair.ac.id

Received: 10 February 2019 Accepted: 14 March 2019 Published: 28 March 2019

Publishing services provided by Knowledge E

(c) Achsania Hendratmi and Bayu Laksana. This article is distributed under the terms of the Creative Commons.

Attribution License, which permits unrestricted use and redistribution provided that the original author and source are credited.

Selection and Peer-review under the responsibility of the ICIEBP Conference Committee. is Siddiq, Amanah, Fathanah and Tabligh, while the endogenous variable is the brand loyalty of the customers.

The result showed that Siddiq. Amanah, Fatanah and Tabligh significantly affect students' satisfaction, by F score equals to 97.062 with significance level (probability) at 0.000. The score for $t$ test of Shiddiq, Amanah, Fathanah, and Tabligh partially affected the brand loyalty of the customers with the significance level equals to $<0.05$.

Keywords: Islamic Brand Personality, Brand Loyalty

\section{Introduction}

\subsection{Background of the study}

Currently a brand has an important competitively in terms of creating and Background of The Study maintaining loyal customers, which one of them is through brand competition. role for a product or service. Brands are also The company's competition is often a tool for consumers to make fighting for consumers is no longer limited to decisions. In addition, the existence of the product use, but has been linked to a brand is able to attract consumers to use brand that is able to provide a special the product.

The importance of building a image for the user, in other words the role brand S OPEN ACCESS has become necessity for of the brand is shifting (Aaker, 1991). In Islam companies in 
marketing the goods or itself the brand has also been associated services offered and in order to compete with marketing (Kartajaya, 2006:8) stated with other companies. Competition in the increasingly tight business world makes companies look for the right strategies to market their products. Hence, every company is required to compete competitively in terms of creating and maintaining loyal customers, which one of them is through brand competition.

The company's competition is fighting for consumers is no longer limited to product use, but has been linked to a brand that is able to provide a special image for the user, in other words the role of the brand is shifting (Aaker, 1991). In Islam itself the brand has also been associated with marketing (Kartajaya, 2006:8) stated that Syariah Marketing is a business accompanied by sincerity solely to seek the pleasure of Allah, then all forms of transaction, insya Allah, become a form of worship before Allah SWT.

This will be the basic capital for it to grow into a larger business, which has a spiritual brand, that has unparalleled charisma, excellence and uniqueness.

Today's marketing management education has focused a lot on how to build successful brands in the midst of an increasingly globalized era (Abou dkk, 2003). (Handoko, 2000: 10) explain that the concept of marketing that is oriented to consumers (consumer oriented) bases that the marketing activities of a company must begin with an effort to recognize and formulate the desires and needs of its costumers. After that the company drafted the marketing mix concept to market its product. (Kotler, 2003: 450) emphasized that there was another marketing mix strategy used to market products in the form of services called 7P (Product, Price, Place, Promotion, People, Process, Physical evidence).

In a product there is a brand, the current brand is not just the identity of a product, or as a differentiator from a competitor's product. Today's society sees a brand as the most important part of a product, so the brand can be an added value in the product. Brands can indicate a certain level of quality, so satisfied buyers can more easily choose a product (Kotler and Keller, 2008). Within the scope of the brand itself there is another element, namely brand equity is the added value given to products and services and is an important intangible asset, which has psychological and financial value for the company (Kotler and Keller, 2008).

According to Aaker (1991) as it is mentioned in Nora (2011: 2) brand equity is

- multi-dimensional concept that include brand loyalty, brand awareness, precieved quality, brand associations and other propietary brand assets. 
The added value of a brand itself has now grown where the brand personality becomes something interesting in the field of marketing how to retain consumers to remain loyal to their products with the brand personality/brand values according to Aaker (in Yin Lin, 2010:5) Brand personality is a series of human characters connected through a brand. In recent years the concept of a brand personality has become a hot topic in marketing, especially in building a new brand.

In accordance to (in Yin Lin, 2010:6) there are five dimensions in brand personality where these dimensions consist of fifteen basic characteristics that help facilitate understanding of the descriptions of each dimension. These dimension including sincerity (down to earth, honest, wholesome, cheerful), excitement (daring, spirited, imaginative, up-to-date), competence (reliable, intelligent, successful), sophistication (upper class, charming), ruggedness (outdoorsy, though). Personality that is reflected through these dimensions can help consumers in assessing and concluding which character is owned by a brand, if consumers feel that personality is a desired character, it will cause a brand preference.

Resources, where humans are the driving factor of other resources such as natural resources or technology from an organization or an agency. The success of an organization both large and small is not solely determined by natural resources or available technology, but is largely determined by the quality of human resources who play a role, in planning, implementing and controlling the organization (Manullang 2005).

In Islam Temporal (2011: 103-104) argues that brand personality is one of the important elements for building an emotional brand strategy. A brand must have "charisma" that can make the brand different from other brands. The reason why Islamic values can build a brand, it is because Islam itself is able to utilize religious values in order to build a broad brand appeal to Muslim and non-Muslim communities (Temporal, 2011:105). A study of Islamic values shows that these values come from various sources, namely: the Holy Qur'an, the behaviour of the Prophet Muhammad, other Prophet's practices, such as Joseph, Ismail, and Idris as examples, and 99 names of Allah SWT (Temporal, 2011:105). There are 4 values in Islam that can be used as indicators of Islamic brand personality, namely: shiddiq (true and honest), amanah (trustworthy and responsible), fathanah (smart and wise), tabligh (communicative).

The increasingly tight competition of Islamic banking today will indirectly affect a shariah financial institution in maintaining market share. To be able to survive the increasingly fierce competition, companies are required to pay more attention to the needs and desires of consumers, especially in strategies to maintain consumer loyalty. 
(Aaker, 1997:56) define brand loyalty as a measure of costumer linkages to a brand. This measure is able to provide an overview of whether or not a costumer might switch to another brand offered by a competitor, especially if there is a change in the brand, whether regarding price or other attributes. Whereas in Islam itself loyalty can be called Istiqomah. Istiqomah is a form of inner quality that gives birth to a consistent and firm attitude to uphold and shape something towards perfection or better conditions (Tasmara, 2001:203).

Having a deep relationship with customers is very important. In addition, marketers must be able to attract attention and bind consumer loyalty, rather than developing strategies to attract new consumers. Therefore, the brand is able to become a mainstay weapon to attract attention and bind consumer's loyalty. (Aaker, 1997:56) define that brand loyalty as a measure of costumer linkages to a brand. This measure is able to provide an overview of whether a costumer might switch to another brand offered by a competitor.

Based on the background above, this study was made to see the effect of job stress on Islamic performance of nursing staff of Aisyiah Bojonegoro Hospital, so the title of this research writing is The Influence of Job Stress on Islamic Performance of Nursing Department of Aisyiah Bojonegoro Hospital.

\subsection{Statement of problems}

Based on the background of the problems that have been described previously, then the statements of the problem in this study is:

1. Does the Islamic brand personality (Shiddiq) have a significant effect on brand loyalty for Bank Muamalat costumers?

2. Does the Islamic brand personality (Amanah have a significant effect on brand loyalty for Bank Muamalat costumers?

3. Does the Islamic brand personality (Fathanah) have a significant effect on brand loyalty for Bank Muamalat costumers?

4. Does the Islamic brand personality (Tabligh) have a significant effect on brand loyalty for Bank Muamalat costumers?

\subsection{The purpose of study}

The objectives that wanted to be achieved in this study are: 
1. To measure and analyse the influence of Islamic brand personality (Shiddiq) on brand loyalty (customers loyalty) of Bank Muamalat Surabaya customers, Mas Mansyur's subsidiary branch.

2. To measure and analyse the influence of Islamic brand personality (Amanah) on brand loyalty (customers loyalty) of Bank Muamalat Surabaya customers, Mas Mansyur's subsidiary branch.

3. To measure and analyse the influence oflslamicbrandpersonality (Fathanah) on brand loyalty (customers loyalty) of Bank Muamalat Surabaya customers, Mas Mansyur's subsidiary branch.

4. To measure and analyse the influence of Islamic brand personality (Tabligh) on brand loyalty (customers loyalty) of Bank Muamalat Surabaya customers, Mas Mansyur's subsidiary branch.

\section{Theoretical Framework and Hypotheses' Development}

\subsection{Brand personality}

(Aaker, 1997:348) defineing the brand personality as a series of human characteristics associated with a brand. Brand personality is formed through consumer attitudes towards a particular brand. In other words, the personality of a brand is in the mind or perception of consumers that are formed directly or indirectly through direct experience in using the product or through marketing efforts. This shows that the brand personality tends to be symbolic and can be a means of consumer self-expression and instruments in helping consumers express different aspects of themselves (Aaker, 1997:348).

\subsection{Islamic brand personality}

(Temporal, 2011: 103) argues that brand personality is one of the important elements for building an emotional brand strategy. A brand must have "charisma" that can make the brand different from other brands. A brand manager must be able to build emotional relationships between brands and consumers by campaigning for brand values that are in line with their target customers. Islam can build a brand because Islam itself is able to utilize religious values in order to build a broad brand appeal to the Muslim and non-Muslim communities (Temporal, 2011:105). A brand must also contain good values, such as the qualities contained in the Prophet Muhammad SAW is an example of a 
brand that has high values as is trusted so that everyone who transacts with them is not necessarily lied to or deceived. (Tasmara, 2001:231) explain the nature of the Prophet, among others are:

1. Shiddiq (true and trustworthy).

2. Amanah (trusted and credible).

3. Fathanah (intelligent).

4. Thabligh (communicative).

\subsubsection{Shiddiq}

Shiddiq is a something that prioritizes and maintains dignity with integrity which begins with a sincere intention and heart and is accompanied by clear, open and speak correctly, transparently, accountability, commendable attitude and exemplary behaviour (Ryandono, 2008:124).

\subsubsection{Amanah}

Amanah means guarding the principle of prudence and honesty in managing funds obtained from fund owners (shahibul maal) so that mutual trust between fund owners and investment fund managers arises (mudharib) (Anshori, 2007:170)

\subsubsection{Fathanah}

According to (Hafidhuddin, 2003:74) fathanah is understanding, conceiving and living deeply in all things. This fathonah nature will foster the ability to do various kinds of useful innovations.

\subsubsection{Tabligh}

(Hafidhuddin, 2003:75) defining tabligh as inviting as well as giving examples to other parties to implement the provisions of Islamic teachings in daily life. Tabligh values have provided content that covers aspects of communication skills, leadership, development and improvement of the quality of human resources, and the ability to manage things (Tasmara, 2001:223). 


\subsubsection{Brand loyalty}

Brand loyalty is the core of brand equity which is the idea in marketing, because it is a measure of a customer's relationship to a brand. Definition of brand loyalty according to (Aaker, 1997:57) is a measure of a customer's relationship to a brand Consumer loyalty to a brand begins from the cognitive stage to the affective stage and develops to the conative stage. At the cognitive stage consumer loyalty is still low, whereas in the affective stage consumers already have a liking for a brand, and finally in the conative stage consumers are willing to recommend the brand to others (word of mouth). According to (Aaker, 1991:34) there are five levels of loyalty, those are, switcher, habitual buyer, satisfied buyer, likes the brand, committed buyer.

\subsubsection{Type of analysis}

Based on the hypotheses above, then in this study, the analysis is used with a research framework to explain the specific relationship between exogenous variables and endogenous variables. The analysis type of this study is explained as follows:

\section{Shiddiq}

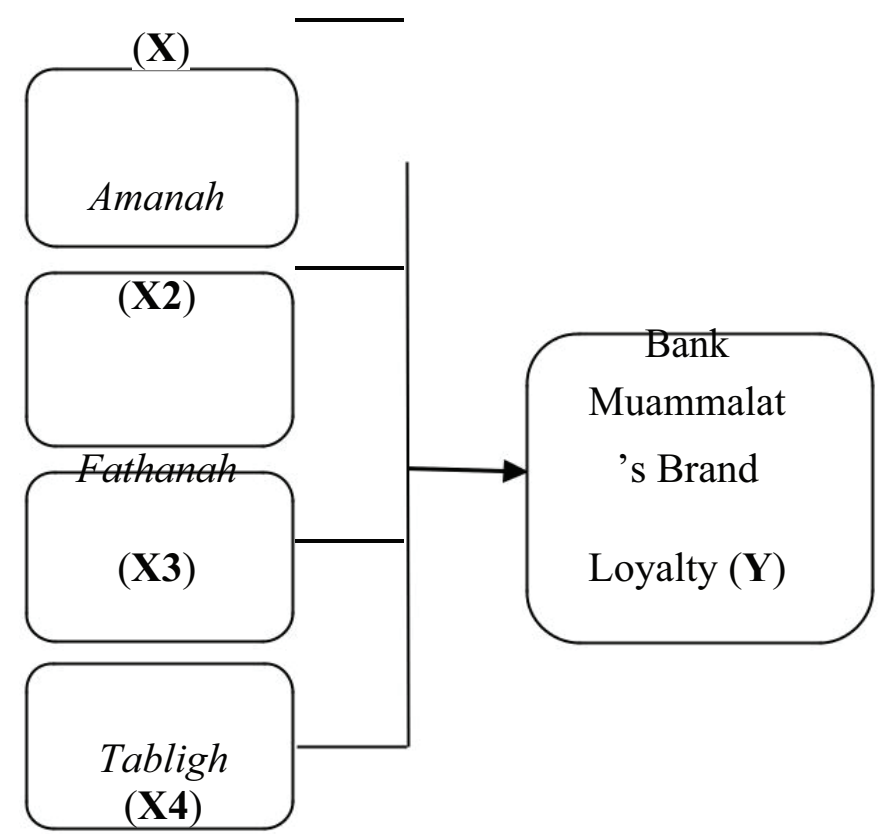

Figure 1: Type of Analysis (Source: Processed from various sources). 


\section{Research Methods}

This study is using several research variable which are: Shiddiq, Amanah, Tabligh, and Fathanah as exogenous variable $(X)$ and brand loyalty of Bank Muamalat as endogenous variable $(Y)$. Shiddiq variable from 3 indicators used as a question item, Amanah consists of 2 indicators which are used as question items, Fathanah consists of 3 indicators used as a question item and Tabligh consists of 2 indicators used as question items. While the brand loyalty variable Bank Muamalat consists of 4 indicators used as question items.

Validity test in this study uses a corrected item-total correlation test whose overall variables are considered valid because the indicators on the variable $>0.3$. Reliability test uses Alpha Cronbach which all variables produce Alpha above 0.6 so that it is considered reliable.

The measurement scale in this study is modified using likert scale model that uses four answers, namely: (SS) Strongly agree score 4, (S) Agree score 3, (TS) Disagree score 2, (STS) Strongly disagree score 1 The source of data used is primary data obtained through a list of questionnaire questions that have been filled in by the respondent.

The population in this study is that all customers of Bank Muamalat have used Bank Muamalat products.

The sampling technique in this study is Non-Probability Sampling, which is a sampling technique that does not provide equal opportunities or opportunities for each element or member of the population to be selected as a sample (Sugiyono, 2012:84). The sampling technique used was purposive sampling and accidental sampling. Purposive sampling is used because the sample in this study are customers of Bank Syariah Mandiri Surabaya, therefore, with consideration and criteria for choosing customers who have become customers of Bank Syariah Mandiri and have never used internet banking services but have known internet banking services. Whereas accidental sampling is a chance-based sampling technique, that anyone who happens to meet with a researcher can be used as a sample, if in the view of someone who happens to be found suitable as a data source (Sugiyono, 2012:85). Ferdinand (2006) stated that in multivariate research (including those using multiple regression analysis) the size of the sample is determined as much as 25 times the independent variable. In this study there were 4 independent $25 \times 4$ variables (number of independent variables) $=100$ samples. The sample of this study were 100 people who had not previously used internet banking at Bank Syariah Mandiri Surabaya. 
Using purposive sampling because the sample in this study is the customer of Bank Muamalat Surabaya therefore with consideration and criteria for choosing customers who have become customers of Bank Muamalat. According to Ferdinand, (2006) In multivariate research (including those using multiple regression analysis) the size of the sample was determined 25 times the independent variable. In this study there were 4 independent variables $25 \times 4$ (number of independent variables) $=100$ samples. The sample of this study is 100 people who have used Bank Muamalat products.

This study uses multiple regression analysis techniques. Multiple linear regression analysis is an analysis of regression models that have more than one exogenous variable.

\section{Result and Discussion}

In this study multiple linear regression analysis was chosen because the test aims to determine the effect of independent variables on the dependent variable with interval scale data. Based on the result of data management, the regression equation in this study is:

\subsection{Multiple linear regression}

TABLE 1: Multiple Linear Regression (Source: Data processed (appendix)).

\begin{tabular}{|l|c|c|c|c|}
\hline Variable & $\begin{array}{c}\text { Regression } \\
\text { Coefficient }\end{array}$ & Beta & tcount & Sig. \\
\hline Constant & 0,126 & & 0.814 & 0,417 \\
\hline Shiddiq (honest) & 0,158 & 0,156 & 2.036 & .0044 \\
\hline Amanah (trustworthy) & 0,256 & 0,246 & 2.000 & .048 \\
\hline Fathanah (professional) & 0,280 & 0,278 & 2.446 & .016 \\
\hline Tabligh (communicative) & 0,244 & 0,269 & 2.640 & .010 \\
\hline F count & & 97,062 & & \\
\hline Significant & & 0.000 & & \\
\hline R & & 0.886 & & \\
\hline$R^{2}$ & & 0.786 & & \\
\hline & & & &
\end{tabular}

Table 1 above stated that the adjusted R2 value or the multiple determination coefficient value of 0,786 . This shows that the independent variables consisting of shiddiq, 
amanah, fathanah, and tabligh altogether influence the brand loyalty by $78,6 \%$. Meanwhile the remaining $21,4 \%$ is influenced by other variables which not included in the study.

Based on the results of the regression calculation above, the regression equation can be formulated as follows:

$$
Y=0.126+0.158 X 1+0.256 X 2+0.280 X 3+0.244 X 4
$$

Regression coefficients with positive signs indicate changes in the direction of the independent variable to the dependent variable. In the calculation shows all the independent variables have positive-signed coefficients, hence, they give certain meanings as below:

1. $\mathrm{X} 1=0.158$

The regression coefficient of an honest variable (shiqqid)(X1) of 0.158 indicates that each increase in honesty (shiqqid)(X1), the Muammalat Bank Brand Loyalty (Y) will increase with a regression coefficient of 0.158 and assuming other variables are constant.

2. $X 2=0.256$

The variable regression coefficient responsible (amanah) (X2) of 0.256 indicates that each variable of responsible (amanah)(X2) is increase, then Muammalat Bank Brand Loyalty $(Y)$ will increase with a regression coefficient of 0.256 and assuming other variables are constant.

3. $\mathrm{X} 3=0.280$

The variable regression coefficient professional (fathanah) (X3) of 0.280 indicates that each variable of professional (fathanah) (X3) is increase, then Muammalat Bank Brand Loyalty $(Y)$ will increase with a regression coefficient of 0.280 and assuming other variables are constant.

4. $X 4=0.244$

The variable regression coefficient communicative (tabligh) (X4) of 0.244 indicates that each variable of communicative (tabligh) (X4) is increase, then Muammalat Bank Brand Loyalty $(Y)$ will increase with a regression coefficient of 0.244 and assuming other variables are constant.

\subsection{The results of the classical assumption testing of the analysis model}




\subsubsection{Multicollinearity test}

In testing the classic assumption of multiple regression analysis, theis study does not occur in multicoll or non multicol because the VIF values of each variable are shiddiq, amanah, fathanah, and tabligh less than 10. Besides that, it can also be seen from the tolerance value. All variables above are free of multicollinearity because the tolerance values are above 0,1 .

\subsubsection{Heteroscedasticity test}

In this study the significance value for all variables is greater than 0,05. Thus, it can be concluded that there are homoscedasticity symptoms or there is no relationship between residual or residual values with the independent variables, so that the dependent variable is really only explained by the independent variable.

\subsubsection{Normality test}

Normality test data shows that the confounding or residual variables in the regression model are normally distributed. The test results are presented in Figure 2.

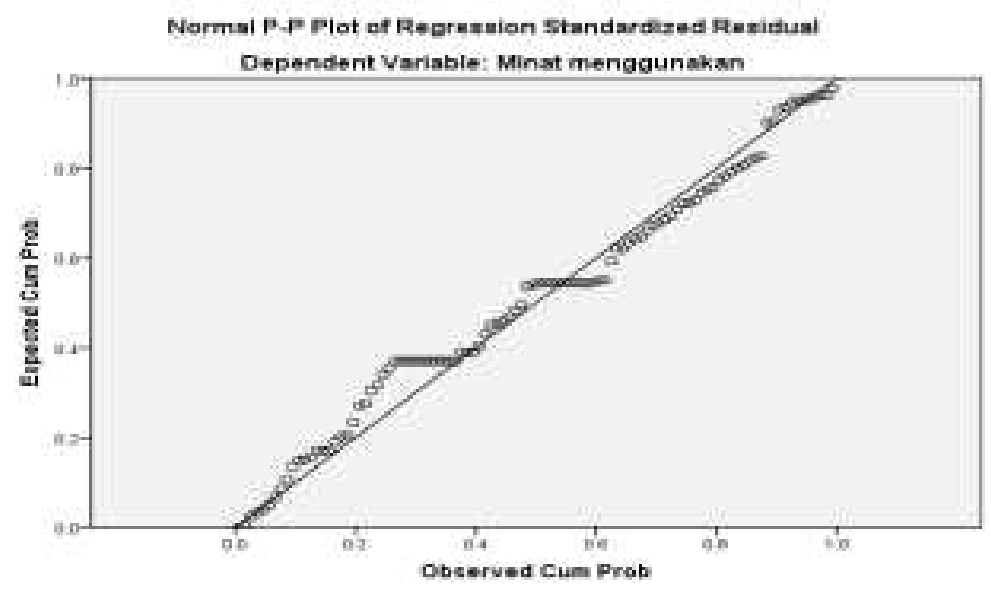

Figure 2: Normality Graph Data (Source: Data (processed)).

The figure above presents that the points spread in an orderly manner around the axis of the diagonal line and follow the direction of the diagonal line, and hence, the data used is normal or the regression model meets the assumption of normality. 
TABLE 2: Test Results of F Test.

\begin{tabular}{l|c|c|c|c|c|c|} 
Model & $\begin{array}{c}\text { Sum of } \\
\text { Squares }\end{array}$ & df & Mean Square & F.count & Sig. \\
\hline Regression & 22.599 & 4 & 5.65 & 97.62 & $.000 a$ \\
\hline Residual & 6.17 & 106 & 0.058 & & \\
\hline Total & 28.768 & 110 & & & \\
\hline
\end{tabular}

\subsubsection{F test}

The test results show that the calculated $F$ value $>F$ table is $97.062(97.062>2,46)$. The more F.count is much larger than $\mathrm{F}$ table means the more significant and the significance level of $F$ test is $0,000(p<0.05)$. It can be concluded that variable X1 Shiddiq (Honest), X2 Amanah (responsible), X3 Fathanah (professional), and X4 (Tabligh (communicative) has simultaneous effect on the Muammalat Bank Brand Loyalty variable $(Y)$.

\subsection{5. $t$ test}

TABLE 3: Decision Making from the Test Results of tcount.

\begin{tabular}{|c|c|c|c|}
\hline Variable & tcount & Significance & Information \\
\hline Shiddiq & 2,036 & $0.044<0,05$ & $\begin{array}{l}\text { Significant } \\
\text { influence }\end{array}$ \\
\hline Amanah & 2,000 & $0.048<0,05$ & $\begin{array}{l}\text { Significant } \\
\text { influence }\end{array}$ \\
\hline Fathanah & 2,446 & $0.016<0,05$ & $\begin{array}{l}\text { Significant } \\
\text { influence }\end{array}$ \\
\hline
\end{tabular}

Based on table 4.25 above, it can be seen that the comparison of the significance value of $t$ count $>t$ table, namely, $(2,036>1,983),(2,000>1,983),(2,446>1,983)$, $(2,640>1,983)$ then it can be concluded that the four independent variables have partial effect on the dependent variable. Then the hypothesis which states that it is suspected X1 Shiddiq (Honest), X2 Amanah (responsible), X3 Fathanah (professional), dan X4 (Tabligh (communicative) significantly influence the Brand Loyalty of Bank Muammalat $(\mathrm{Y})$. 


\section{Discussion}

Based on the analysis of the overall research results obtained that through the $F$ test the value with a significant value of 0,000 $<0,05$ which has meaning that Shiddiq, Amanah, Fathanah, Tabligh altogether significantly influence the customer brand loyalty of Bank Muammalat Surabaya.

The partial test results show that all variables in the research significance value of $t$ test is smaller than 0.05, which means that Shiddiq, Amanah, Fathanah, Tabligh significantly influence the customer brand loyalty of Bank Muamalat Surabaya.

Thus, the hypothesis which states that whether Shiddiq, Amanah, Fathanah, Tabligh significantly influence the brand loyalty of Bank Muamalat Surabaya customers is accepted.

\section{Suggestions}

After going through the research process, several suggestions that can be given as an input to the company are:

1. Bank Muamalat is expected to further enhance personality of Shiddiq (honest) in their brand that was previously attached to Bank Muammalat will still be a brand that represents honesty values. Hence the customers increasingly believe in the brand promised by Bank Muamalat, namely as the first honest shariah bank and Islamic institutions that work in the financial sector, not just a bank that is run with shariah system, morality and aqidah. Because some of Bank Muammalat's customers are Muslims who holds the values of honesty.

2. Bank Muamalat is expected to continue to improve the personality of its brand through the provision of fathanah (professional) services as promised by the brand of Bank Muammalat, as a bank that has integrity, sincerity and competence so that customers are also more istiqomah/consistent with the Bank Muammalat brand.

\section{References}

[1] Aaker, D.A. 1991. Managing Brand Equity, New York: Free Press

[2] Aaker, Jennifer L. 1997. Dimensions of Brand Personality. Journal of Marketing Research. Vol.34 No.3. p: 347-356

[3] Aaker, D.A. (1997). Ekuitas Merek. Jakarta: penerbit Mitra Utama 
[4] Abdul Ghofur Anshori, Perbankan Syariah Di Indonesia, Yogyakarta, Gadjah Mada University Press, 2007, hal 170 Anshori, Muslich dan Sri Iswati. 2009. Metodologi Penelitiian Kuantitatif. Surabaya: Airlangga University Press.

[5] Assael, H. (1998). Consumer Behavior and Marketing Action. '6th Edition. Cincinati, $\mathrm{OH}$ : Sout-Westeren College Publishing.

[6] Basu Swasta Dharmmesta dan T. Hani Handoko, 2000. Manajemen Pemasaran, Analisa Perilaku Konsumen (Edisi Pertama, Yogyakarta,: BPFE).

[7] Hermawan, Asep. 2005. Penelitian Bisnis: Paradigma Kuantitatif. Jakarta: Grasindo

[8] Illandoyo. 2001. Stres Manajemen Sukses Dalam Sepekan. Editor: Fathudin. Jakarta: Kesaint Blanc

[9] Kartajaya, Hermawan dan Muhammad Syakir Sula. 2006. Syariah Marketing. Bandung: PT Mizan Pustaka.

[10] Kotler, Philip. Manajemen Pemasaran Edisi Milenium. Edisi 2. Terjemahan oleh Prentice-Hall. 2002. Jakarta: Pearson Education Asia Pte. Ltd. Dan PT Prenhallindo.

[11] Kotler, 2003. Marketing Management, International Edition, New Jersey: Prentice Hall,

[12] Kotler, Philip. Manajemen Pemasaran di Indonesia : Analisis perencanaan, implementasi dan pengendalian.

[13] Jilid 1. 2006. Jakarta: Salemba Empat.

[14] Kotler, Philip dan Kevin Lane Keller. 2009. Manajemen Pemasaran. Edisi 13 Jilid 1. Jakarta: Erlangga.

[15] Keller, Kevin Lane. 2008. Strategic Brand Management: Building, Measuring, and Managing Brand Equity. 3rd edition. United states of America: Pearson - Prentice Hall

[16] Latief, Wasis A. 2011. Analisis Faktor Psikologis Konsumen dan Pengaruhnya Terhadap Keputusan Pembelian. Jurnal Administrasi Indonesia, Vol.1, No.1

[17] Lin, Long-Yi. 2010. The Relationship of Consumer Personality Trait, Brand Personality and Brand Loyalty: an Empirical Study of Toys and Video Games Buyers. Journal of product and brand management, (online), Volume 19. No.2. 417, (http://www.emeraldinsight.com/1 061-0421.htm).

[18] Muflih, Muhammad. 2006. Perilaku Konsumen dalam Perspektif IImu Ekonomi Is/am. Jakarta: PT RajaGrafindo Persada. Journal of contemporary research in bussines, Vol. 3 No 9, page:791-800

[19] Muhammad. 2002. Ekonomi Mikro Dalam Perpestif Islam. Yogyakarta: BPFE 
[20] Rangkuti, 2010. Analisis SWOT Teknik Membedah Kasus Bisnis. Jakarta: PT Gramedia Pustaka Utama.

[21] Rangkuti, Fredy. 2002. "Measuring Customer statisfaction”. PT. Gramedia Pustaka Utama, Jakarta.

[22] Ryandono. Muhammad Nafik Hadi. 2008. Bursa Efek \& Investasi syari'ah. Surabaya: CIEBERD

[23] Satria, 2009. Pengaruh Brand Bank Mandiri Terhadap Brand Equity Bank Syariah Mandiri. Jakarta

[24] Solimun. 2005. Sructural Equation Modeling Lisrel dan Amos. Malang: Fakultas MIPA Unibraw

[25] Sudarsono, Heri. 2003. Bank dan Lembaga Keuangan Syari'ah. Edisi Kedua. Jakarta: Ekonisia.

[26] Sugiyono. 2008. Metode Penelitian Kuantitatif, kualitatif dan R\&D. Cetakan ke-10. Alfabeta: Bandung.

[27] Tasmara, Toto. 2001. Kecerdasan Ruhaniah (Transcedental Intellegence). Jakarta: Gema Insani Press.

[28] Temporal, Paul. 2011. Islamic Brand And Marketing. Singapore: Toppan Security Printing Pte. Ltd.

[29] Temporal, Paul, 2000, Branding In Asia: The Creation, Development and Management of Asian Brands for the Global Market, First Edition, John Wiley and Son, Singapore.

[30] Tjiptono, F. 2002. Manajemen Jasa, Edisi II. Cetakan ketiga, penerbitan Andi Offset, Yogyakarta.

[31] Robbins, Stephen P. dan Timothy A. Judge. Tanpa Tahun. Perilaku Organisasi. Terjemahan oleh Diana Angelica, Ria Cahyani, dan Abdul Rosyid. 2008. Jakarta: Salemba Empat.

[32] Sanusi, Anwar. 2006. Jalan Kebangkitan. Jakarta: Gema Insani Press. Siagian Sondak. 1995. Manajemen Sumber Daya Manusia, Jakarta: Bumi Aksara

[33] Sopiah. 2008. Perilaku Organisasional. Yogyakarta: C.V Andi Offset

[34] Sugiyono. 2010. Metode Penelitian Bisnis: Pendekatan Kuantitatif, Kualitatif, dan $R \& D$. Bandung: Alfabeta. Tasmara,

[35] Toto. 2002. Membudayakan Etos

[36] Kerja Islami. Jakarta: Gema Insani. Yamin, Sofyan \& Kurniawan, Heri. 2009. SPPS Complete. Jakarta: Salemba Infotek. 